\title{
Nitric oxide in follicle development and oocyte competence
}

\author{
Giuseppina Basini and Francesca Grasselli \\ Dipartimento di Scienze Medico-Veterinarie, Università degli Studi di Parma, Via del Taglio 10, I-43126 Parma, Italy \\ Correspondence should be addressed to G Basini; Email: basini@unipr.it
}

\begin{abstract}
Apart from its well-known role in regulating endothelial function, in mammals, nitric oxide (NO) is an important signaling molecule involved in many processes, regulating different biological functions. It has been demonstrated that NO plays a role in the physiology of the reproductive system, where it acts in controlling the activity of reproductive organs in both sexes. In the female of several animal species, experimental data suggest the presence of an intraovarian NO-generating system, which could be involved in the control of follicular development. The role of NO in regulating follicular atresia by apoptosis is still controversial, as a dual action depending mostly on its concentration has been documented. NO also displays positive effects on follicle development and selection related to angiogenic events and it could also play a modulatory role in steroidogenesis in ovarian cells. Both in monovulatory and poliovulatory species, the increase in $\mathrm{PGE}_{2}$ production induced by NO via a stimulatory effect on COX-2 activity appears to be a common ovulatory mechanism. Considerable evidence also exists to support an involvement of the NO/NO synthase system in the control of meiotic maturation of cumulus-oocyte complexes.
\end{abstract}

Reproduction (2015) 150 R1-R9

\section{Introduction}

In the late 1970s, it was recognized that the endothelium releases a factor that relaxes vascular smooth muscle cells, thereby causing vasodilatation (Furchgott \& Zawadzki 1980), and it was named endothelium-derived relaxing factor (EDRF). Later on, EDRF was simultaneously identified by Ignarro et al. (1987) and Palmer et al. (1987) as nitric oxide (NO), a colorless and odorless gas. Several lines of evidence have shown that this gas is a fundamental messenger involved in numerous biological processes and the journal 'Science' entitled NO as 'Molecule of the Year' in 1992 while in 1998 NO discovery merited the Noble prize.

This short-lived radical molecule is synthesized by a complex family of NO synthase (NOS) enzymes. It is produced by the oxidation and cleavage of one of the terminal nitrogen atoms of the amino acid L-arginine. Mammalian cells are endowed with three genes encoding distinct isoforms of NOS, NOS1, NOS2, and NOS3, which share a $51-57 \%$ homology. These isoforms show different tissue localizations, regulation, and inhibitor sensitivity. NOS1, also known as neuronal NOS (nNOS) (first isolated from neuronal tissue), and NOS3 or endothelial NOS (eNOS) (first found in endothelium) are constitutive and activated by an increase in calcium, thus producing low transient concentrations of NO. On the contrary, NOS2 is an inducible NOS (iNOS) and calcium-independent isoform (Daff 2010). In addition, a mitochondrial NOS was described by Kobzik et al. (1995). Since then, several studies were addressed in order to characterize the isoform identity, its regulation, and its involvement in physiological or pathological events (Finocchietto et al. 2009, Zaobornyj \& Ghafourifar 2012, Geary et al. 2014).

NO can be generated independently from NOS by reduction of nitrite, which can occur spontaneously under hypoxic and/or acidic conditions (Cortese-Krott et al. 2015). Enzymes such as xanthine oxidase and cytochrome oxidase $c$ can also mediate reduction of nitrite (Zweier et al. 1995, Godber et al. 2000).

Differently from conventional biosignaling molecules, $\mathrm{NO}$ activity is not mediated by its binding to receptors. Instead, NO easily diffuses into cells and exerts its bioactivity directly acting on many signaling pathways (Moncada et al. 1991).

Owing to its unpaired electron, NO displays a high reactivity with many biological components (Grisham et al. 1999). One of the most physiologically relevant reactions is that with heme proteins, which can result in the formation of stable chemical species. This is particularly important as the activation of guanylate cyclase, the main effector for $\mathrm{NO}$ activity, is due to NO binding to heme moiety in the enzyme, thus resulting in an increased cGMP production (Denninger \& Marletta 1999). 
NO itself has a short life in vivo because of its reactivity with hemoglobin and a broad spectrum of other biological components (Grisham et al. 1999). As a free radical, $\mathrm{NO}$ can react with other molecules. Moreover, NO may be formed and/or bioactivated as nitroxyl or nitrosonium, which can be stabilized in biological complexes with thiols, nitrite and other intermediates. In addition, several biomolecules can react with $\mathrm{NO}$, thus resulting in nitration (addition of $\mathrm{NO}_{2}$ ), nitrosation (addition of $\mathrm{NO}^{+}$), and nitrosylation (addition of NO) (Moncada et al. 1991).

$\mathrm{NO}$ acts as an important intra- and inter-cellular messenger adjusting numerous functions, primarily that of the vascular endothelium. Its role in the maintenance of small arteries and basal tone of arterioles is supported by experimental observations documenting an increase in blood pressure resulting from the administration of the NOS inhibitor in different animal species (Chatterjee et al. 2008).

The presence of a 'nitrergic' nervous system, composed of NO-releasing nerves previously classified as nonadrenergic, non-cholinergic, has been hypothesized in the cardiovascular, respiratory, and urinary system. In the CNS, NO displays different effects, being involved in the mechanisms of memory formation (Katusic \& Austin 2014).
The sustained NO production by iNOS in activated macrophages is important in host defense against infection (Wink et al. 2011).

Moreover, on the basis of animal and in vitro studies, it has been shown that NO may modulate endocrine system function (Vargas et al. 2007).

Therefore, as hormones, neurons, blood vessels, and cells of the immune systems are integral parts of the reproductive organs, it is likely that NO functions (Fig. 1) as an important regulator of the biology and physiology of the reproductive system, where it acts in regulating multiple functions within the female as well as the male reproductive organs.

First of all, NO is involved in the control of gonadotropin secretion both with a direct effect and via a regulatory effect on hypothalamic $\mathrm{GnRH}$ release (Bellefontaine et al. 2011).

$\mathrm{NO}$ is a physiological mediator of erectile function (Yetik-Anacak et al. 2014) and testicular cells are well equipped with a NO-cGMP pathway, which may participate in the regulation of testicular functions, such as spermatogenesis and steroidogenesis (Ducsay \& Myers 2011). A physiological role for NO in regulating oviduct function and biology of the uterus that has gained intense attention (Toda et al. 2013) has been

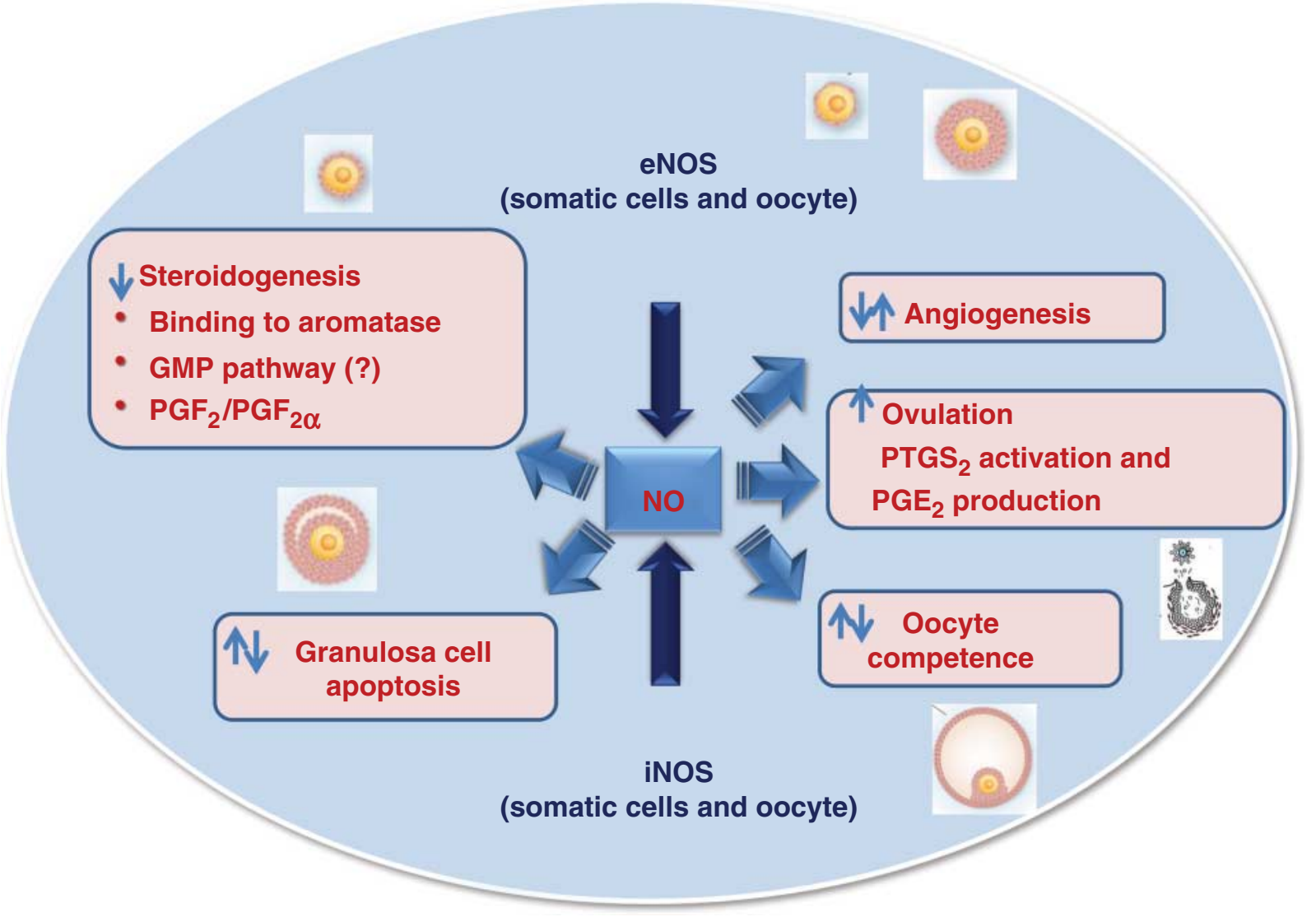

Figure 1 Follicular events controlled by NO. 
proposed (Chang \& Hsu 2013). As for the ovary, it is still unclear whether these effects are due to $\mathrm{NO}$ generated in the vasculature and neurons within the ovary or directly attributable to $\mathrm{NO}$ generated by various cells within the ovary. In order to get an insight into these findings, in this review, we will concentrate on the role of $\mathrm{NO}$ in the control of ovarian follicle development and oocyte competence.

\section{NO in follicle development}

\section{Regulation of NO production}

Pituitary gonadotropins are well recognized as key regulators of the final stages of follicular development, but a growing body of evidence underlines the importance of the intrafollicular balance of autocrine or paracrine factors in driving normal follicular growth.

The presence of $\mathrm{NO}$ in follicular fluid has been confirmed in several animal species, and the demonstration of NOS expression suggests the presence of an intraovarian NO-generating system and emphasizes its role in the control of follicular development (Fig. 1).

The major regulator of NO production is NOS, which appears in three isoforms: nNOS, eNOS, and iNOS. In the ovary, NO can be generated by several ovarian cells and within the ovarian vasculature; resident macrophages have also been indicated as a possible source of $\mathrm{NO}$ (Dave et al. 1997). As for the ovarian cells, many studies have been carried out to examine the expression and localization patterns of NOS isoforms in the ovary of different species.

The localization of NOS isoforms in several mammalian ovaries was reported, but the results were not consistent. In the rat, Zhang et al. (2011) demonstrated cellular expression and immunolocalization of three different NOS isoforms in the ovary before puberty. In adult rats, several authors assessed the expression of eNOS in granulosa cells, thecal layer, and ovarian stroma (Zackrisson et al. 1996, Jablonka-Shariff \& Olson 1997, Jablonka-Shariff et al. 1999, Nakamura et al. 1999, Yamagata et al. 2002), while iNOS was localized only in somatic cells of follicle and luteal cells (JablonkaShariff \& Olson 1997, Tao et al. 1997, Yamagata et al. 2002). Even though eNOS has been considered a constitutively expressed enzyme isoform, many experimental works document that the pattern of protein and mRNA expression within the ovary is subjected to changes during follicular and luteal phases of the estrous cycle. Gonadotropin stimulation induces an increase in eNOS mRNA levels, which are highest during the periovulatory period (Van Voorhis et al. 1995), as well as an enhanced protein expression (Jablonka-Shariff \& Olson 1997). iNOS expression has also been documented in the rat ovary, but different regulatory mechanisms have been proposed for this isoform.

iNOS mRNA is undetectable in gonadotropinstimulated ovulatory follicles (Van Voorhis et al. 1995) and cannot be induced by follicle-stimulating hormone (FSH) in granulosa cells; in fact, both its expression and activity seem to require IL1 beta stimulation (Tabraue et al. 1997). In accordance with these findings, Matsumi et al. (2000) documented NO production by iNOS only in immature follicles as well as a decrease in iNOS mRNA levels induced by gonadotropin administration. These data would support the hypothesis of a role played by iNOS as a cytostatic factor in the earlier stages of rat follicular development.

In the mouse, Mitchell et al. (2004) found that both eNOS and iNOS were expressed in theca and granulosa cells where iNOS occurred predominantly.

Among monovulatory species, NOS expression has been scarcely investigated in humans but eNOS was demonstrated within granulosa-lutein cells (Van Voorhis et al. 1994).

In the bovine, Pires et al. (2009) demonstrated that eNOS is detectable in theca, granulosa, surface epithelium, and corpus luteum, and that $\mathrm{NO}$ is necessary for follicle development. In addition, Moonmanee et al. (2013) pointed out a relationship among eNOS expression, vascularization, and mitotic activity in the first follicular wave, thus suggesting a role for eNOS in selection of nonovulatory dominant follicles. Herath etal. (2007) did not detect iNOS mRNA in ruminant granulosa cells, while Zamberlam et al. (2011) documented the expression of iNOS in the same cells and its regulation by FSH and insulin-like growth factor 1, probably mediated by estradiol. These observations would support the hypothesis that, in this species, endogenous NO production could be involved in follicle selection. NO has been detected in ruminant follicular fluids (Basini et al. 1998, Khan \& Das 2011, EL-Sherry et al. 2013), with higher concentrations in small follicle (Basini et al. 1998, Khan \& Das 2011). Different results were documented by Pancarci et al. (2011) who measured the lowest NO levels in bovine dominant follicles.

Grazul-Bilska et al. (2006) reported an increase in eNOS protein expression around ovulation in ewes, suggesting a regulatory role of $\mathrm{NO}$ in the ovulatory process. Perifollicular blood flow is positively related to NO concentrations both in the bovine and ovine (Pancarci et al. 2012, EL-Sherry et al. 2013) ovaries.

A preliminary study on the buffalo (Dubey et al. 2012) demonstrated the presence of all the NOS isoforms in the different stages of ovarian follicles, from preantral to ovulatory. NO appears to be involved in follicular development in this species, but the exact definition of its role requires further research.

In the horse, Pinto et al. (2003) found that NO is detectable in preovulatory follicular fluids and its concentration increases after administration of hCG, thus suggesting its involvement in the ovulatory cascade.

It appears that, in porcine ovary, eNOS is found more frequently than iNOS. Porcine granulosa cells represent a site of NO production (Grasselli et al. 2002); the presence 
of iNOS mRNA cannot be confirmed in granulosa cells from swine antral follicles (Grasselli et al. 2001, Takesue et al. 2001); eNOS mRNA expression in cultured porcine granulosa cells has been shown to depend upon FSH stimulation (Takesue et al. 2001). Physiological hypoxia taking place during follicle growth could be an important factor inhibiting NO synthesis in swine granulosa cells (Basini et al. 2004). In addition, it has been demonstrated that NO production by swine granulosa cells is modulated by physiological peptides (Basini et al. 2011, 2014) as well as by endocrine disruptors (Santini et al. 2009, Basini et al. 2012).

\section{Role of NO in the control of follicular growth and atresia}

In the mammalian ovary, more than $99 \%$ of ovarian follicles undergo a degenerative process called atresia. Follicular atresia is a selective process during follicular growth that involves granulosa cell death by apoptosis. Many researchers described mechanisms that regulate apoptotic cell death during follicular atresia. An involvement of $\mathrm{NO}$ in modulating these events has been postulated as this molecule appears to be involved in controlling cell growth and death in several cell types. In the follicle, the role of $\mathrm{NO}$ in these events is controversial as it can be toxic or protective mostly depending on its concentration. This dual effect has been clearly evidenced in the buffalo by Dubey et al. (2011) and in the bovine by Basini et al. (1998). Several studies (Matsumi et al. 1998, Yoon et al. 2002, Chen et al. 2005) point out a protective effect of NO vs apoptosis in rat follicles. This finding has also been reported in human granulosa cells (Dineva et al. 2008). Sugino et al. (1996) postulated that internucleosomal DNA cleavage resulting in DNA fragmentation could be mediated by NO in small follicles but not in large ones. Large follicles probably possess a tonic inhibitory system suppressing apoptotic DNA cleavage.

Data supporting NO antiapoptotic effects have been documented by Zamberlam et al. (2011), who hypothesized that increased NO levels in the bovine dominant follicle would inhibit FasL-mediated apoptosis.

On the contrary, in the chicken, NO appears to be involved in follicle regression (Sundaresan et al. 2007).

\section{Role of NO in the control of follicular steroidogenesis}

The steroidogenic pathway within the follicle gives rise to progestins, androgens, and estrogens, all of them acting via specific nuclear receptors to regulate reproductive functions and to maintain fertility. As sex steroids play an important role in the growth and differentiation of reproductive tissues, different factors that impair their production usually compromise fertility.
NO has been demonstrated to inhibit follicular steroidogenesis in rats (Dave et al. 1997, Shahpar et al. 2007), human (Van Voorhis et al. 1994, Rosselli et al. 1998, Tobai \& Nishiya 2001), bovine (Basini et al. 1998, Basini \& Tamanini 2000, Faes et al. 2009), buffalo (Dubey et al. 2011), and swine (Masuda et al. 1997, Matsumi et al. 2000, Ponderato et al. 2000, Grasselli et al. 2001). NO exerts its effects by binding to the prosthetic heme group of enzymes. Thus, NO may directly bind to P450 aromatase, a key enzyme in the steroidogenic pathway (Hanke et al. 1998). The activation of soluble guanylate cyclase is another mechanism of steroid inhibition mediated by NO. However, conflicting results have been obtained in different species, possibly owing to different culture conditions. In fact, in cultured granulosa cells from mice (Ishimaru et al. 2001) and pigs (Grasselli et al. 2001), the NO/cGMP pathway has been suggested as one of the mechanisms used by $\mathrm{NO}$ to inhibit steroidogenesis, while this effect appear to be cGMP independent in human (Van Voorhis et al. 1994) and bovine (Basini et al. 2000). In addition, Basini \& Tamanini (2001) suggest that the inhibitory effect of $\mathrm{NO}$ on bovine granulosa cell steroidogenesis could be at least partially mediated by $\mathrm{PGE}_{2}$ and $\mathrm{PGF}_{2 \alpha}$ and a crosstalk between NOS and COX metabolites can be hypothesized.

\section{Role of NO in the control of follicular angiogenesis}

Follicle development is dependent on the establishment and continual remodeling of a complex vascular system. This enables the follicle to receive the required supply of nutrients, oxygen, and hormonal support as well as facilitating the release of steroids. During the transition from avascular primary follicle to a vascular secondary follicle, angiogenesis occurs in the theca layer but the mechanisms by which the secondary follicle becomes endowed with vasculature remain unclear. This transition may be due to local transformation of mesenchymal cells into endothelial cells or active migration of endothelial cell precursors from preexisting blood vessels. Apart from the effect of $\mathrm{NO}$ on follicular blood flow demonstrated in the rat (Griffith 1994, Zackrisson et al. 2000, Mitsube et al. 2002) and human (Zackrisson et al. 1996), suppressive effects of NO on angiogenesis in the bovine follicle have been postulated by observing a negative relationship between VEGF and NO levels in porcine granulosa cells (Grasselli et al. 2002).

The modulatory role of $\mathrm{NO}$ on the follicular angiogenic process appears still controversial at the present time, as positive effects of $\mathrm{NO}$ on follicle development and selection related to angiogenic events have been instead demonstrated in bovine (GrazulBilska et al. 2007, Tessaro et al. 2011), horse (Pinto et al. 2003), and sheep (Seekallu et al. 2010). 


\section{Role of NO on follicular prostaglandin secretion and ovulation}

The ovulatory cascade is triggered by a surge of luteinizing hormone (LH), which induces a molecular machinery in which $\mathrm{NO}$ exerts a crucial role at least in rodents (Shukovski \& Tsafriri 1994) and rabbits (Hesla et al. 1997), mainly increasing prostaglandin production. The prostaglandin-endoperoxide synthases (PTGS) are the key enzymes that mediate the synthesis of prostaglandins, PTGS1, constitutively expressed in most cells involved in maintaining homeostatic functions, and PTGS2, very low under normal physiological conditions but rapidly induced by several stimuli and known to exert a pivotal role in ovulation (Sugimoto et al. 2015). NO is able to induce PTGS2 expression in several cell types.

The involvement of $\mathrm{NO}$ in monovulatory species ovulation was demonstrated for the first time in sheep (Grazul-Bilska et al. 2006). More recently, both in bovine (Zamberlam et al. 2014) and human (Fang et al. 2015) the central role of $\mathrm{NO}$ in stimulating PTGS2 activation and $\mathrm{PGE}_{2}$ production has been confirmed.

Therefore, taken together, the increase in $\mathrm{PGE}_{2}$ production induced by $\mathrm{NO}$ via a stimulatory effect on PTGS2 activity appears to be a common mechanism in both monovulatory and poliovulatory species.

\section{NO in oocyte competence}

The mechanisms involved in the regulation of meiotic cell cycle in oocytes are not fully understood yet, but considerable evidence exists to support an involvement of the NO/NOS system in the control of meiotic maturation of cumulus-oocyte complexes. NO is now thought to represent a vital component of the oocyte microenvironment as it plays a physiological role during oocyte maturation, fertilization, and beginning of embryo development (Jablonka-Shariff \& Olson 1998, Sengoku et al. 2001, Bergandi et al. 2014).

eNOS and iNOS expression has been documented in mammalian oocytes (mice: Mitchell et al. (2004); rat: Jablonka-Shariff \& Olson (1998); cattle: Tesfaye et al. (2006); Pires et al. (2009); pig: Chmelíková et al. (2009)) and their presence was confirmed throughout folliculogenesis and follicle maturation (Chmelíková 00000000000et al. 2009, Pires et al. 2009). As for nNOS, its presence in oocytes has been documented only in the pig (Chmelíková et al. 2009), and its mRNA in the mouse (Abe et al. 1999).

Further confirmation of $\mathrm{NO}$ role in oocyte maturation comes from studies on eNOS knockout mice (JablonkaShariff \& Olson 1998), which display an impairment of ovulation and a higher percentage of atypical oocytes. Recently, Goud et al. (2014) have confirmed their previous observations about the role played by $\mathrm{NO}$ in delaying mouse oocyte aging. The inhibition of $\mathrm{NO}$ synthesis during IVM decreases the number of blastocysts
(Matta et al. 2009) and increases apoptosis in embryos (Schwarz et al. 2010). On the other hand, high NO levels have been reported to impair meiotic progression and embryonic development in cattle (Schwarz et al. 2008). Other evidence exists that $\mathrm{NO}$ donors would prevent or delay meiotic resumption in the rat (Nakamura et al. 2002, Bu et al. 2004, Sela-Abramovich et al. 2006), cattle (Schwarz et al. 2014), and pigs (Tao et al. 2005), while iNOS-specific inhibitors induce meiotic resumption (Nakamura et al. 2002). Recently, Goud et al. (2014) have confirmed that $\mathrm{NO}$ plays a significant role in maintaining oocyte quality. The controversial effects reported in these studies would suggest that $\mathrm{NO}$ can play a dual function in oocyte maturation, as already highlighted with regard to its modulatory role on follicular function (Tamanini et al. 2003). Bu et al. (2003) documented NO paradoxical effects on mouse oocyte maturation depending on its concentration: eNOS-derived NO from cumulus cells stimulates meiotic maturation of mouse oocytes at low doses, while a milieu of high concentrations of $\mathrm{NO}$ would maintain the meiotic arrest of oocytes (Nakamura et al. 2002). The decrease in $\mathrm{NO}$ after LH preovulatory surge may be a key factor for meiosis resumption: as a consequence of the activation of MAPK, the disruption of gap junctional communication would stop the transfer of inhibitory substances from granulosa cells to the oocyte, enabling it to resume meiosis (Sela-Abramovich et al. 2008).

Different findings indicate that the oocyte itself possesses the ability to produce adequate NO levels through iNOS-mediated pathway required for the maintenance of meiotic arrest at diplotene stage (Tripathi et al. 2010).

NO levels thus appear as a critical factor in cell survival and physiology. In a study on the effect of varying $\mathrm{NO}$ concentrations on bovine oocyte nuclear maturation, Bilodeau-Goeseels (2007) reported that germinal vesicle breakdown in cumulus-enclosed oocytes was prevented or stimulated by high or low doses of the NO donor SNP respectively. These observations would suggest that $\mathrm{NO}$ reduction, possibly linked to transcript reduction in eNOS, is necessary for germinal vesicle breakdown (Tesfaye et al. 2006, Pires et al. 2009) and meiosis resumption.

As for NO signaling pathways, cGMP has been documented as a crucial factor in maintaining the meiotic arrest in oocytes (Nakamura et al. 2002), but the role played by $\mathrm{NO}$ in the cGMP/cAMP pathway during meiosis resumption is not completely known and still a matter of study. Schwarz et al. (2014) have recently confirmed that the progression of meiosis in bovine oocytes is linked to the inactivation of the $\mathrm{NO}$ /guanylate cyclase/cGMP pathway, but did not observe a significant involvement of cAMP levels in oocyte maturation. Different results have been reported by BilodeauGoeseels (2007) in the same species, who hypothesized that the NO-induced reduction of germinal vesicle 
breakdown rate would not be exerted via sGC/sGMP. Abbasi et al. (2009) suggested that the stimulatory effect of $\mathrm{NO}$ on mice oocyte meiotic resumption would involve cAMP, while the cGMP pathway would be involved in mediating the inhibitory effect of NO. High cGMP levels produced by iNOS-derived NO could maintain meiotic arrest of preovulatory oocytes via two different pathways. One would involve inhibition of oocyte cAMP phosphodiesterase to maintain CAMP levels, and a second one the activation of cGMPdependent protein kinase (Törnell et al. 1991).

\section{Concluding remarks}

After 1987, when EDRF was identified as NO, this simple molecule has been shown to be involved in many physiological functions. The demonstration of NO effects on neurons, endothelial cells, immune cells, and endocrine cells qualifies this molecule as a regulator of ovarian follicle, a structure that comprises all these cell types. In the follicle, NO controls the main functional activities such as growth or atresia, angiogenesis, steroidogenesis, and ovulatory events. In addition, NO has been shown to represent a vital component of the oocyte microenvironment, where it plays a physiological role during oocyte maturation and the acquisition of competence. Therefore, the ability to manipulate the players of the NO system could represent a promising tool to interfere with the follicular growth dynamics and ovulation.

\section{Declaration of interest}

The authors declare that there is no conflict of interest that could be perceived as prejudicing the impartiality of the review.

\section{Funding}

This review was supported by a grant from the Università degli Studi di Parma (FIL).

\section{References}

Abbasi M, Akbari M, Amidi F, RagerdiKashani I, Mahmoudi R, Sobhani A, Takzare N, Pasbakhsh P, Barbarestani M, Abolhassani F et al. 2009 Nitric oxide through different signalling pathways in maturation of cumulus cell-enclosed mouse oocytes. DARU Journal of Pharmaceutical Sciences 17 48-52.

Abe K, Matsuoka K, Inoue N, Taga M \& Kato T 1999 Messenger RNA of neuronal nitric oxide synthase is expressed and possibly functions in mouse oocytes and embryos during preimplantation development. Biomedical Research 20 61-65.

Basini G \& Tamanini C 2000 Selenium stimulates estradiol production in bovine granulosa cells: possible involvement of nitric oxide. Domestic Animal Endocrinology 18 1-17. (doi:10.1016/S0739-7240(99)00059-4)

Basini G \& Tamanini C 2001 Interrelationship between nitric oxide and prostaglandins in bovine granulosa cells. Prostaglandins and Other Lipid Mediators 66 179-202. (doi:10.1016/S0090-6980(01)00156-3)
Basini G, Baratta M, Ponderato N, Bussolati S \& Tamanini C 1998 Is nitric oxide an autocrine modulator of bovine granulosa cell function? Reproduction, Fertility and Development 10 471-478. (doi:10.1071/ RD98114)

Basini G, Grasselli F, Ponderato N, Bussolati S \& Tamanini C 2000 Lipid hydroperoxide and CGMP are not involved in nitric oxide inhibition of steroidogenesis in bovine granulosa cells. Reproduction, Fertility, and Development 12 289-295. (doi:10.1071/RD00089)

Basini G, Bianco F, Grasselli F, Tirelli M, Bussolati S \& Tamanini C 2004 The effects of reduced oxygen tension on swine granulosa cell. Regulatory Peptides 120 69-75. (doi:10.1016/j.regpep.2004.02.013)

Basini G, Cortimiglia C, Baioni L, Bussolati S, Grolli S, Ramoni R \& Grasselli F 2011 The axonal guidance factor netrin-1 as a potential modulator of swine follicular function. Molecular and Cellular Endocrinology 331 41-48. (doi:10.1016/j.mce.2010.08.001)

Basini G, Bianchi F, Bussolati S, Baioni L, Ramoni R, Grolli S, Conti V, Bianchi F \& Grasselli F 2012 Atrazine disrupts steroidogenesis, VEGF and $\mathrm{NO}$ production in swine granulosa cells. Ecotoxicology and Environmental Safety 85 59-63. (doi:10.1016/j.ecoenv.2012.08.027)

Basini G, Baioni L, Bussolati S, Grolli S \& Grasselli F 2014 Prolactin is a potential physiological modulator of swine ovarian follicle function. Regulatory Peptides 189 22-30. (doi:10.1016/j.regpep.2014.01.003)

Bellefontaine N, Hanchate NK, Parkash J, Campagne C, de Seranno S, Clasadonte J, d'Anglemont de Tassigny X \& Prevot V 2011 Nitric oxide as key mediator of neuron-to-neuron and endothelial-to-glia communication involved in the neuroendocrine control of reproduction. Neuroendocrinology 93 74-89. (doi:10.1159/000324147)

Bergandi L, Basso G, Evangelista F, Canosa S, Dalmasso P, Aldieri E, Revelli A, Benedetto C \& Ghigo D 2014 Inducible nitric oxide synthase and heme oxygenase 1 are expressed in human cumulus cells and may be used as biomarkers of oocyte competence. Reproductive Sciences $\mathbf{2 1}$ 1370-1377. (doi:10.1177/1933719114525268)

Bilodeau-Goeseels S 2007 Effects on manipulating the nitric oxide/cyclic GMP pathway on bovine oocyte meiotic resumption in vitro. Theriogenology 68 693-701. (doi:10.1016/j.theriogenology.2007.05.063)

Bu S, Xia G, Tao Y, Lei L \& Zhou B 2003 Dual effects on meiotic maturation of mouse cumuls cell-enclosed oocytes in vitro. Molecular and Cellular Endocrinology 207 21-30. (doi:10.1016/S0303-7207(03) 00213-2)

Bu S, Xie H, Tao Y, Wang J \& Xia G 2004 Nitric oxide influences the maturation of cumulus cell-enclosed mouse oocytes cultured in spontaneous maturation medium and hypoxanthine-supplemented medium through different signaling pathways. Molecular and Cellular Endocrinology 223 85-93. (doi:10.1016/j.mce.2004.04.015)

Chang CL \& Hsu SY 2013 Roles of CLR/RAMP receptor signaling in reproduction and development. Current Protein \& Peptide Science 14 393-406. (doi:10.2174/13892037113149990056)

Chatterjee A, Black SM \& Catravas JD 2008 Endothelial nitric oxide (NO) and its pathophysiologic regulation. Vascular Pharmacology 49 134-140. (doi:10.1016/j.vph.2008.06.008)

Chen Q, Yano T, Matsumi H, Osuga Y, Yano N, Xu J, Wada O, Koga K, Fujiwara T, Kugu K et al. 2005 Cross-Talk between Fas/Fas ligand system and nitric oxide in the pathway subserving granulosa cell apoptosis: a possible regulatory mechanism for ovarian follicle atresia. Endocrinology 146 808-815. (doi:10.1210/en.2004-0579)

Chmelíková E, Sedmíková M, Petr J, Kott T, Lánská V, Tûmová L, Tichovská H \& Ješeta M 2009 Expression and localization of nitric oxide synthase isoforms during porcine oocyte growth and acquisition of meiotic competence. Czech Journal of Animal Science 54 137-149.

Cortese-Krott MM, Fernandez BO, Kelm M, Butler AR \& Feelisch M 2015 On the chemical biology of the nitrite/sulfide interaction. Nitric Oxide $\mathbf{4 6}$ 14-24. (doi:10.1016/j.niox.2014.12.009)

Daff S 2010 NO synthase: structures and mechanisms. Nitric Oxide 23 1-11. (doi:10.1016/j.niox.2010.03.001)

Dave S, Farrance DP \& Whitehead SA 1997 Evidence that nitric oxide inhibits steroidogenesis in cultured rat granulosa cells. Clinical Science 92 277-284. (doi:10.1042/cs0920277)

Denninger JW \& Marletta MA 1999 Guanylate cyclase and the .NO/cGMP signaling pathway. Biochimica et Biophysica Acta 1411 334-350. (doi:10.1016/S0005-2728(99)00024-9) 
Dineva JD, Vangelov IM, Nikolov GG, Konakchieva RTs \& Ivanova MD 2008 Nitric oxide stimulates the production of atrial natriuretic peptide and progesterone by human granulosa luteinized cells with an antiapoptotic effect. Endocrine Regulations 42 45-51.

Dubey PK, Tripathi V, Singh RP \& Sharma GT 2011 Influence of nitric oxide on in vitro growth, survival, steroidogenesis, and apoptosis of follicle stimulating hormone stimulated buffalo (Bubalus bubalis) preantral follicles. Journal of Veterinary Science 12 257-265. (doi:10.4142/jvs. 2011.12.3.257)

Dubey PK, Tripathi V, Singh RP, Saikumar G, Nath A, Pratheesh MD, Gade N \& Sharma GT 2012 Expression of nitric oxide synthase isoforms in different stages of buffalo (Bubalus bubalis) ovarian follicles: effect of nitric oxide on in vitro development of preantral follicle. Theriogenology 77 280-291. (doi:10.1016/j.theriogenology.2011.08.002)

Ducsay CA \& Myers DA 2011 eNOS activation and NO function: differential control of steroidogenesis by nitric oxide and its adaptation with hypoxia. Journal of Endocrinology 210 259-269. (doi:10.1530/JOE11-0034)

El-Sherry TM, Derar R \& Bakry R 2013 Changes in blood flow in ovine follicles and serum concentration of estradiol $17 \beta\left(E_{2}\right)$ and nitric oxide (NO) around the time of ovulation in Ossimi ewes. Animal Reproduction Science 138 188-193. (doi:10.1016/j.anireprosci.2013.02.019)

Faes MR, Caldas-Bussiere MC, Viana KS, Dias BL, Costa FR \& Escocard RM 2009 Nitric oxide regulates steroid synthesis by bovine antral granulosa cells in a chemically defined medium. Animal Reproduction Science $\mathbf{1 1 0}$ 222-236. (doi:10.1016/j.anireprosci.2008.01.018)

Fang L, Chang HM, Cheng JC, Leung PC \& Sun YP 2015 Nitric oxide and CGMP induce COX-2 expression and $\mathrm{PGE}_{2}$ production in human granulosa cells through CREB signaling pathway. Journal of Clinical Endocrinology and Metabolism 100 E262-E269. (doi:10.1210/jc.20142886)

Finocchietto PV, Franco MC, Holod S, Gonzalez AS, Converso DP, Antico Arciuch VG, Serra MP, Poderoso JJ \& Carreras MC 2009 Mitochondrial nitric oxide synthase: a masterpiece of metabolic adaptation, cell growth, transformation, and death. Experimental Biology and Medicine 234 1020-1028. (doi:10.3181/0902-MR-81)

Furchgott RF \& Zawadzki JV 1980 The obligatory role of endothelial cells in the relaxation of arterial smooth muscle by acetylcholine. Nature $\mathbf{2 8 8}$ 373-376. (doi:10.1038/288373a0)

Geary K, Knaub LA, Schauer IE, Keller AC, Watson PA, Miller MW, Garat CV, Nadeau KJ, Cree-Green M, Pugazhenthi S et al. 2014 Targeting mitochondria to restore failed adaptation to exercise in diabetes. Biochemical Society Transactions 42 231-238. (doi:10.1042/ BST20130283)

Godber BL, Doel JJ, Sapkota GP, Blake DR, Stevens CR, Eisenthal R \& Harrison R 2000 Reduction of nitrite to nitric oxide catalyzed by xanthine oxidoreductase. Journal of Biological Chemistry 275 7757-7763. (doi:10.1074/jbc.275.11.7757)

Goud PT, Goud AP, Najafi T, Gonik B, Diamond MP, Saed GM, Zhang X \& Abu-Soud HM 2014 Direct real-time measurement of intra-oocyte nitric oxide concentration in vivo. PLoS ONE 9 e98720. (doi:10.1371/journal. pone.0098720)

Grasselli F, Ponderato N, Basini G \& Tamanini C 2001 Nitric oxide synthase expression and nitric oxide/cyclic GMP pathway in swine granulosa cells. Domestic Animal Endocrinology 20 241-252. (doi:10.1016/ S0739-7240(01)00096-0)

Grasselli F, Basini G, Bussolati S \& Tamanini C 2002 Effects of VEGF and bFGF on proliferation and production of steroids and nitric oxide in porcine granulosa cells. Reproduction in Domestic Animals 37 362-368. (doi:10.1046/j.1439-0531.2002.00386.x)

Grazul-Bilska AT, Navanukraw C, Johnson ML, Arnold DA, Reynolds LP \& Redmer DA 2006a Expression of endothelial nitric oxide synthase in the ovine ovary throughout the estrous cycle. Reproduction 132 579-587. (doi:10.1530/REP-06-0009)

Grazul-Bilska AT, Navanukraw C, Johnson ML, Vonnahme KA, Ford SP, Reynolds LP \& Redmer DA 2007 Vascularity and expression of angiogenic factors in bovine dominant follicles of the first follicular wave. Journal of Animal Science 85 1914-1922. (doi:10.2527/jas.20070044)

Griffith TM 1994 Modulation of blood flow and tissue perfusion by endothelium-derived relaxing factor. Experimental Physiology $\mathbf{7 9}$ 873-913. (doi:10.1113/expphysiol.1994.sp003816)
Grisham MB, Jour'dheuil D \& Wink DA 1999 Nitric oxide: I. Physiological chemistry of nitric oxide and its metabolites: implications in inflammation. American Journal of Physiology. Gastrointestinal and Liver Physiology 39 G315-G321.

Hanke CJ, Drewett JG, Myers CR \& Campbell WB 1998 Nitric oxide inhibits aldosterone synthesis by a guanylyl cyclase-independent effect. Endocrinology 139 4053-4060. (doi:10.1210/endo.139.10.6252)

Herath S, Williams EJ, Lilly ST, Gilbert RO, Dobson H, Bryant CE \& Sheldon IM 2007 Ovarian follicular cells have innate immune capabilities that modulate their endocrine function. Reproduction 134 683-693. (doi:10.1530/REP-07-0229)

Hesla JS, Preutthipan S, Maguire MP, Chang TS, Wallach EE \& Dharmarajan AM 1997 Nitric oxide modulates human chorionic gonadotropin-induced ovulation in the rabbit. Fertility and Sterility $\mathbf{6 7}$ 548-552. (doi:10.1016/S0015-0282(97)80084-2)

Ignarro LJ, Buga GM, Wood KS, Byrns RE \& Chaudhuri G 1987 Endothelium derived relaxing factor produced and released from artery and vein is nitric oxide. PNAS 84 9265-9269. (doi:10.1073/pnas.84.24.9265)

Ishimaru RS, Leung K, Hong L \& LaPolt PS 2001 Inhibitory effects of nitric oxide on estrogen production and cAMP levels in rat granulosa cell cultures. Journal of Endocrinology 168 249-255. (doi:10.1677/joe.0.1680249)

Jablonka-Shariff A \& Olson LM 1997 Hormonal regulation of nitric oxide synthases and their cell-specific expression during follicular development in the rat ovary. Endocrinology 138 460-468. (doi:10.1210/endo. 138.1.4884)

Jablonka-Shariff A \& Olson LM 1998 The role of nitric oxide in oocyte meiotic maturation and ovulation: meiotic abnormalities of endothelial nitric oxide synthase knock-out mouse oocytes. Endocrinology 139 2944-2954. (doi:10.1210/endo.139.6.6054)

Jablonka-Shariff A, Basuray R \& Olson LM 1999 Inhibitors of nitric oxide synthase influence oocyte maturation in rats. Journal of the Society for Gynecologic Investigation 6 95-101. (doi:10.1016/S1071-5576(98) 00053-7)

Katusic ZS \& Austin SA 2014 Endothelial nitric oxide: protector of a healthy mind. European Heart Journal 35 888-894. (doi:10.1093/eurheartj/ eht544)

Khan FA \& Das GK 2011 Follicular fluid nitric oxide and ascorbic acid concentrations in relation to follicle size, functional status and stage of estrous cycle in buffalo. Animal Reproduction Science 125 62-68. (doi:10.1016/j.anireprosci.2011.03.012)

Kobzik I, Stringer B, Ballingand JL, Reid MB \& Stamler JS 1995 Endothelial type nitric oxide synthase in skeletal muscle fibers: mithocondrial relationships. Biochemistry and Biophysics Research Communications 211 375-381. (doi:10.1006/bbrc.1995.1824)

Masuda M, Kubota T, Karnada S \& Aso T 1997 Nitric oxide inhibits steroidogenesis in cultured porcine granulosa cells. Molecular Human Reproduction 3 285-292. (doi:10.1093/molehr/3.4.285)

Matsumi H, Koji T, Yano T, Yano N, Tsutsumi O, Momoeda M, Osuga Y \& Taketani $Y 1998$ Evidence for an inverse relationship between apoptosis and inducible nitric oxide synthase expression in rat granulosa cells: a possible role of nitric oxide in ovarian follicle atresia. Endocrine Journal 45 745-751. (doi:10.1507/endocrj.45.745)

Matsumi H, Yano T, Osuga Y, Kugu K, Tang X, Xu JP, Yano N, Kurashima Y, Ogura T, Tsutsumi $O$ et al. 2000 Regulation of nitric oxide synthase to promote cytostasis in ovarian follicular development. Biology of Reproduction 63 141-146. (doi:10.1095/biolreprod63.1.141)

Matta SG, Caldas-Bussiere MC, Viana KS, Faes MR, Paes de Carvalho CS, Dias BL \& Quirino CR 2009 Effect of inhibition of synthesis of inducible nitric oxide synthase-derived nitric oxide by aminoguanidine on the in vitro maturation of oocyte-cumulus complexes of cattle. Animal Reproduction Science 111 189-201. (doi:10.1016/j.anireprosci.2008. 03.002)

Mitchell LM, Kennedy CR \& Hartshorne GM 2004 Expression of nitric oxide synthase and effect of substrate manipulation of the nitric oxide pathway in mouse ovarian follicles. Human Reproduction 19 30-40. (doi:10.1093/humrep/deh032)

Mitsube K, Zackrisson U \& Brännström M 2002 Nitric oxide regulates ovarian blood flow in the rat during the periovulatory period. Human Reproduction 17 2509-2516. (doi:10.1093/humrep/17.10.2509)

Moncada S, Palmer RM \& Higgs EA 1991 Nitric oxide: physiology, pathology, and pharmacology. Pharmacological Reviews 43 109-142. 
Moonmanee T, Navanukraw C, Uriyapongson S, Kraisoon A, Aiumlamai S, Guntaprom S, Rittirod T, Borowicz PP \& Redmer DA 2013 Relationships among vasculature, mitotic activity, and endothelial nitric oxide synthase (eNOS) in bovine antral follicles of the first follicular wave. Domestic Animal Endocrinology 45 11-21. (doi:10.1016/j.domaniend. 2013.03.002)

Nakamura H, Tsukada H, Oya M, Onomura M, Saito T, Fukuda K, Kodama M, Taniguchi T, Tominaga M, Hosokawa M et al. 1999 Aminoguanidine has both an anti-inflammatory effect on experimental colitis and a proliferative effect on colonic mucosal cells. Scandinavian Journal of Gastroenterology 34 1117-1122. (doi:10.1080/003655299750024922)

Nakamura Y, Yamagata Y, Sugino N, Takayama H \& Kato H 2002 Nitric oxide inhibits oocyte meiotic maturation. Biology of Reproduction 67 1588-1592. (doi:10.1095/biolreprod.102.005264)

Palmer RM, Ferrige AG \& Moncada S 1987 Nitric oxide release accounts for the biological activity of endothelial-derived relaxing factor. Nature 327 524-526. (doi:10.1038/327524a0)

Pancarcı SM, Güngör O, Atakişi O, Ciğremiş Y, Arı UÇ \& Bollwein H 2011 Changes in follicular blood flow and nitric oxide levels in follicular fluid during follicular deviation in cows. Animal Reproduction Science 123 149-156. (doi:10.1016/j.anireprosci.2011.01.001)

Pancarci SM, Ari UÇ, Atakisi O, Güngör O, Ciğremiş Y \& Bollwein H 2012 Nitric oxide concentrations, estradiol- $17 \beta$ progesterone ratio in follicular fluid, and COC quality with respect to perifollicular blood flow in cows. Animal Reproduction Science 130 9-15. (doi:10.1016/j.anireprosci. 2011.12.013)

Pinto CR, Paccamonti DL, Eilts BE, Venugopal CS, Short CR, Gentry LR, Thompson DL Jr \& Godke RA 2003 Concentrations of nitric oxide in equine preovulatory follicles before and after administration of human chorionic gonadotropin. Theriogenology 60 819-827. (doi:10.1016/ S0093-691X(03)00096-7)

Pires PR, Santos NP, Adona PR, Natori MM, Schwarz KR, de Bem TH \& Leal CL 2009 Endothelial and inducible nitric oxide synthases in oocytes of cattle. Animal Reproduction Science 116 233-243. (doi:10.1016/j. anireprosci.2009.02.019)

Ponderato N, Grasselli F, Saleri R \& Tamanini C 2000 Factors modulating apoptosis: an in-vitro study in swine granulosa cells. Reproduction in Domestic Animals 35 213-219. (doi:10.1046/j.1439-0531.2000. 00217.x)

Rosselli M, Keller PJ \& Dubey RK 1998 Role of nitric oxide in the biology, physiology and pathophysiology of reproduction. Human Reproduction Update 4 3-24. (doi:10.1093/humupd/4.1.3)

Santini SE, Basini G, Bussolati S \& Grasselli F 2009 The phytoestrogen quercetin impairs steroidogenesis and angiogenesis in swine granulosa cells in vitro. Journal of Biomedicine and Biotechnology 2009419891. (doi:10.1155/2009/419891)

Schwarz KR, Pires PR, Adona PR, Câmara de Bem TH \& Leal CL 2008 Influence of nitric oxide during maturation on bovine oocyte meiosis and embryo development in vitro. Reproduction, Fertility, and Development 20 529-536. (doi:10.1071/RD07209)

Schwarz KR, Pires P, De Bem T, Adona P \& Leal CL 2010 Consequences of nitric oxide synthase inhibition during bovine oocyte maturation on meiosis and embryo development. Reproduction in Domestic Animals 45 75-80. (doi:10.1111/j.1439-0531.2008.01242.x)

Schwarz KR, Pires PR, Mesquita LG, Chiaratti MR \& Leal CL 2014 Effect of nitric oxide on the cyclic guanosine monophosphate (cGMP) pathway during meiosis resumption in bovine oocytes. Theriogenology $\mathbf{8 1}$ 556-564. (doi:10.1016/j.theriogenology.2013.11.008)

Seekallu SV, Toosi BM, Grazul-Bilska AT \& Rawlings NC 2010 Markers of ovarian antral follicular development in sheep: comparison of follicles destined to ovulate from the final or penultimate follicular wave of the estrous cycle. Reproduction 140 559-568. (doi:10.1530/REP-10-0064)

Sela-Abramovich S, Edry I, Galiani D, Nevo N \& Dekel N 2006 Disruption of gap junctional communication within the ovarian follicle induces oocyte maturation. Endocrinology 147 2280-2286. (doi:10.1210/ en.2005-1011)

Sela-Abramovich S, Galiani D, Nevo N \& Dekel N 2008 Inhibition of rat oocyte maturation and ovulation by nitric oxide: mechanism of action. Biology of Reproduction 78 1111-1118. (doi:10.1095/biolreprod.107. 065490)

Sengoku K, Takuma N, Horikawa M, Tsuchiya K, Komori H, Sharifa D, Tamate K \& Ishikawa M 2001 Requirement of nitric oxide for murine oocyte maturation, embryo development, and trophoblast outgrowth in vitro. Molecular Reproduction and Development 58 262-268. (doi:10.1002/1098-2795(200103)58:3 < 262::AID-MRD3 > 3.0.CO;2-8)

Shahpar S, Minoo I, Vahid N \& Goudarz SH 2007 Physiological effects of NO-cGMP pathway on ovarian steroidogenesis in rat. Pakistan Journal of Biological Sciences 10 1175-1179. (doi:10.3923/pjbs.2007.1175.1179)

Shukovski L \& Tsafriri A 1994 The involvement of nitric oxide in the ovulatory process in the rat. Endocrinology 135 2287-2290. (doi:10. 1210/endo.135.5.7525265)

Sugimoto Y, Inazumi T \& Tsuchiya S 2015 Roles of prostaglandin receptors in female reproducticon. Journal of Biochemistry 157 73-80. (doi:10.1093/jb/mvu081)

Sugino N, Takiguchi S, Ono M, Tamura H, Shimamura K, Nakamura Y, Tsuruta R, Sadamitsu D, Ueda T, Maekawa T et al. 1996 Nitric oxide concentrations in the follicular fluid and apoptosis of granulosa cells in human follicles. Human Reproduction 11 2484-2487. (doi:10.1093/ oxfordjournals.humrep.a019144)

Sundaresan NR, Saxena VK, Sastry KV, Anish D, Saxena M, Nagarajan K \& Ahmed KA 2007 Nitric oxide: a possible mediator of ovulation and postovulatory follicle regression in chicken. Animal Reproduction Science 101 351-357. (doi:10.1016/j.anireprosci.2007.01.011)

Tabraue C, Peñate RD, Gallardo G, Hernandez I, Quintana J, Blanco FL, Reyes JG, Fanjul FL \& Ruiz de Galarreta CM 1997 Induction of guanosine triphosphate cyclohydrolase by follicle stimulating hormone enhances interleukin-1- $\beta$ stimulated nitric oxide synthase activity in granulosa cells. Endocrinology 138 162-168. (doi:10.1210/endo.138. 1.4854)

Takesue K, Hattori MA, Nishida N, Kato Y \& Fujihara N 2001 Expression of endothelial nitric oxide synthase gene in cultured porcine granulosa cells after FSH stimulation. Journal of Molecular Endocrinology 26 259-265. (doi:10.1677/jme.0.0260259)

Tamanini C, Basini G, Grasselli F \& Tirelli M 2003 Nitric oxide and the ovary. Journal of Animal Science 81 E1-E7.

Tao M, Kodama H, Kagabu S, Fukuda J, Murata M, Shimizu Y, Hirano H \& Tanaka T 1997 Possible contribution of follicular interleukin-1 $\beta$ to nitric oxide generation in human pre-ovulatory follicles. Human Reproduction 12 2220-2225. (doi:10.1093/humrep/12.10.2220)

Tao Y, Xie H, Hong H, Chen X, Jang J \& Xia G 2005 Effects of nitric oxide synthase inhibitors on porcine oocyte meiotic maturation. Zygote 13 1-9. (doi:10.1017/S0967199404002953)

Tesfaye D, Kadanga A, Rings F, Bauch K, Jennen D, Nganvongpanit K, Hölker M, Tholen E, Ponsuksili S, Wimmers K et al. 2006 The effect of nitric oxide inhibition and temporal expression patterns of the mRNA and protein products of nitric oxide synthase genes during in vitro development of bovine pre-implantation embryos. Reproduction in Domestic Animals $\mathbf{4 1}$ 501-509. (doi:10.1111/j.1439-0531.2006.00701.x)

Tessaro I, Luciano AM, Franciosi F, Lodde V, Corbani D \& Modina SC 2011 The endothelial nitric oxide synthase/nitric oxide system is involved in the defective quality of bovine oocytes from low mid-antral follicle count ovaries. Journal of Animal Science 89 2389-2396. (doi:10.2527/jas. 2010-3714)

Tobai H \& Nishiya I 2001 Nitric oxide mediates inhibitory effect of interleukin- $1 \beta$ on estrogen production in human granulosa-luteal cells. Journal of Obstetrics and Gynaecology Research 27 53-59. (doi:10.1111/j.1447-0756.2001.tb01216.x)

Toda N, Toda H \& Okamura T 2013 Regulation of myometrial circulation and uterine vascular tone by constitutive nitric oxide. European Journal of Pharmacology 714 414-423. (doi:10.1016/j.ejphar.2013.07.006)

Törnell J, Billig H \& Hillensjö T 1991 Regulation of oocyte maturation by changes in ovarian levels of cyclic nucleotides. Human Reproduction 6 411-422.

Tripathi A, Prem Kumar KV \& Chaube SK 2010 Meiotic cell cycle arrest in mammalian oocytes. Journal of Cellular Physiology 223 592-600. (doi:10.1002/jcp.22108)

Van Voorhis BJ, Dunn MS, Snyder GD \& Weiner CP 1994 Nitric oxide: an autocrine regulator of human granulosa-luteal cell steroidogenesis. Endocrinology 135 1799-1806. (doi:10.1210/endo.135.5.7525252)

Van Voorhis BJ, Moore K, Strijbos PJ, Nelson S, Baylis SA, Grzybicki D \& Weiner CP 1995 Expression and localization of Inducible and Endothelial Nitric Oxide Synthase in the Rat Ovary. Journal of Clinical Investigation 96 2719-2726. (doi:10.1172/JCI118339) 
Vargas F, Moreno JM, Wangensteen R, Rodríguez-Gómez I \& GarcíaEstañ J 2007 The endocrine system in chronic nitric oxide deficiency. European Journal of Endocrinology 156 1-12. (doi:10.1530/eje.1.02314)

Wink DA, Hines HB, Cheng RY, Switzer CH, Flores-Santana W, Vitek MP, Ridnour LA \& Colton CA 2011 Nitric oxide and redox mechanisms in the immune response. Journal of Leukocyte Biology 89 873-891. (doi:10.1189/jlb.1010550)

Yamagata Y, Nakamura Y, Umayahara K, Harada A, Takayama H, Sugino N \& Kato H 2002 Changes in telomerase activity in experimentally induced atretic follicles of immature rats. Endocrine Journal 49 589-595. (doi:10.1507/endocrj.49.589)

Yetik-Anacak G, Sorrentino R, Linder AE \& Murat N 2014 Gas what: NO is not the only answer to sexual function. British Journal of Pharmacology 172 1434-1454. (doi:10.1111/bph.12700)

Yoon SJ, Choi KH \& Lee KA 2002 Nitric oxide-mediated inhibition of follicular apoptosis is associated with HSP70 induction and Bax suppression. Molecular Reproduction and Development 61 504-510. (doi:10.1002/mrd.10033)

Zackrisson U, Mikuni M, Wallin A, Delbro D, Hedin L \& Brännström M 1996 Cell-specific localization of nitric oxide synthases (NOS) in the rat ovary during follicular development, ovulation and luteal formation. Human Reproduction 11 2667-2673. (doi:10.1093/oxfordjournals. humrep.a019189)

Zackrisson U, Mikuni M, Peterson MC, Nilsson B, Janson PO \& Brännström M 2000 Evidence for the involvement of blood flow-related mechanisms in the ovulatory process of the rat. Human Reproduction 15 264-272. (doi:10.1093/humrep/15.2.264)
Zamberlam G, Portela V, de Oliveira JF, Gonçalves PB \& Price CA 2011 Regulation of inducible nitric oxide synthase expression in bovine ovarian granulosa cells. Molecular and Cellular Endocrinology 335 189-194. (doi:10.1016/j.mce.2011.01.013)

Zamberlam G, Sahmi F \& Price CA 2014 Nitric oxide synthase activity is critical for the preovulatory epidermal growth factor-like cascade induced by luteinizing hormone in bovine granulosa cells. Free Radical Biology \& Medicine 74 237-244. (doi:10.1016/j.freeradbiomed.2014. 06.018)

Zaobornyj T \& Ghafourifar P 2012 Strategic localization of heart mitochondrial NOS: a review of the evidence. American Journal of Physiology 303 H1283-H1293. (doi:10.1152/ajpheart.00674.2011)

Zhang W, Wei QW, Wang ZC, Ding W, Wang W \& Shi FX 2011 Cellspecific expression and immunolocalization of nitric oxide synthase isoforms and the related nitric oxide/cyclic GMP signaling pathway in the ovaries of neonatal and immature rats. Journal of Zhejiang University. Science. B 12 55-64. (doi:10.1631/jzus.B1000174)

Zweier JL, Wang P, Samouilov A \& Kuppusamy P 1995 Enzyme independent formation of nitric oxide in biological tissues. Nature Medicine 1 804-809. (doi:10.1038/nm0895-804)

Received 3 October 2014

First decision 17 November 2014

Revised manuscript received 16 March 2015

Accepted 19 March 2015 